\title{
Alpha-Ketoglutarate-Dependent Dioxygenase AlkB Homolog 7
}

National Cancer Institute

\section{Source}

National Cancer Institute. Alpha-Ketoglutarate-Dependent Dioxygenase AlkB Homolog

7. NCl Thesaurus. Code C106587.

Alpha-ketog lutarate-dependent dioxygenase alkB homolog 7 (221 aa, $25 \mathrm{kDa}$ ) is

encoded by the human ALKBH7 gene. This protein plays a role in oxidoreductase activity. 